\title{
EMOTIONAL INTELLIGENCE AND SERVICE QUALITY OF FACILITATORS' INDONESIA HUMAN RESOURCES DEVELOPMENT AGENCY (HRDA)
}

\author{
Shine Pintor Siolemba Patiro ${ }^{1}$ and Hety Budiyanti ${ }^{2}$ \\ ${ }^{1}$ Economics Faculty, Open University, Indonesia \\ ${ }^{2}$ Economics Faculty, State University of Makassar, Indonesia \\ E-mail: shinepintor@ecampus.ut.ac.id
}

\begin{abstract}
The model which was widely known and describes the concept of service quality is the Service Quality (SERVQUAL) model proposed by Parasuraman et al (1985). However, this model has a limitation, because its application merely for service providers in the business sector, not for service providers in the public sector and service providers in the education sector. In education sector, facilitators are always involved in interpersonal interaction with the training participants. Some researchers agree to uncover the relationship between the emotional intelligence of service providers and service quality. Based on the literature review, there are limited studies in the field of education and training of the Civil Service Apparatus, especially regarding the relationship between emotional intelligence and service quality. Thus, this study aims to reveal the effect of facilitators' emotional intelligence on service quality with respondents from participants of Basic Education and Training (Diklatsar), Leadership Education and Training 3 (Diklatpim 3), and Leadership and Education Training 4 (Diklatpim 4) at HRDA Province. This study uses quantitative methods. The sample size in this study was 462 people who were collected through a survey with a purposive sampling technique. The data analysis technique used is SEM through a two-stage approach. The results showed that the facilitators' emotional intelligence of HRDA of Central Java, East Java, West Java, Jakarta, Banten, Central Sulawesi, and North Sumatera Provinces, had a significant positive effect on the quality of service with social awareness as the indicator with the highest effect.
\end{abstract}

Key words: Education and Training; Emotional Intelligence; Service Quality; SEM.

\section{KECERDASAN EMOSIONAL DAN KUALITAS PELAYANAN WIDYAISWARA BADAN PENGEMBANGAN SUMBER DAYA MANUSIA DAERAH WILAYAH PROVINSI INDONESIA}

ABSTRAK. Salah satu model yang terkenal mengenai kualitas layanan dan sering digunakan dalam berbagai penelitian di bidang jasa adalah model Service Quality (SERVQUAL) yang dikemukakan oleh Parasuraman et al (1985). Namun, model ini memiliki keterbatasan, karena dalam penerapannya hanya selalu untuk penyedia jasa di sektor jasa maupun manufaktur. Tetapi jarang bahkan sedikit diterapkan untuk penyedia layanan di sektor publik dan penyedia layanan di sektor pendidikan. Di bidang pendidikan, fasilitator selalu terlibat dalam interaksi interpersonal dengan peserta pelatihan. Beberapa peneliti sepakat untuk mengungkap hubungan antara kecerdasan emosional penyedia layanan dan kualitas layanan. Berdasarkan tinjauan pustaka, terdapat keterbatasan kajian di bidang pendidikan dan pelatihan Aparatur Sipil Negara terutama mengenai hubungan antara kecerdasan emosional dan kualitas pelayanan. Penelitian ini bertujuan untuk mengungkap mengenai hubungan antara kecerdasan emosional widyaiswara dengan kualitas pelayanan yang diberikan saat proses pendidikan dan pelatihan di Badan Pengembangan Sumber Daya Manusia Daerah Provinsi melalui persepsi peserta diklat. Para peserta diklat dalam penelitian ini adalah peserta Diklatsar, peserta Diklat PIM 3, dan peserta Diklat PIM 4. Metode penelitian ini adalah kuantitatif dengan teknik pengumpulan data menggunakan survey serta penyampelan purposif. Besaran sampel dalam penelitian adalah 462 responden yang merupakan widyaiswara yang berada di Badan Pengembangan Sumber Daya Manusia Daerah Provinsi Jawa Tengah, Jawa Timur, Jawa Barat, Jakarta, Banten, Sulawesi Tengah, dan Sumatera Utara. Teknik analisis data menggunakan SEM dengan pendekatan dua tahap. Hasil penelitian menunjukkan bahwa kecerdasan emosional widyaiswara di Badan Pengembangan Sumber Daya Manusia Daerah tersebut berpengaruh positip dan signifikan pada kualitas pelayanan dengan kesadaran sosial sebagai variable yang paling berpengaruh.

Kata kunci: Diklat; kecerdasan emosional; kualitas pelayanan; SEM

\section{INTRODUCTION}

Law No. 43/1999 as an amendment to Law No. 8/1974 concerning Personnel Principles states that to achieve national objectives, a civil servant is required to act as a public servant, with full loyalty to Pancasila and the 1945 Constitution. Furthermore, based on Law Number 5 of 2014, civil servants, including as State Civil Apparatuses (CSA), need to have competencies consisting of managerial, technical, and socio-cultural competencies.
Following the law, managerial competence is measured based on the level of education, structural or management training, and leadership experience. Therefore, as CSA, managerial competence is important in their environment when carrying out their duties and responsibilities as emphasized by the central government and regional governments.

Furthermore, as a preparation for a prospective CSA to gain competence is to follow the Basic Training (Latsar). The Latsar is an education and training in the pre-service period carried out in 
an integrated manner to build moral integrity, honesty, enthusiasm, and nationalism, superior and responsible personality traits, strengthen the professionalism and competence of his/her duties by the State Administration Agency Regulation (Perlan) No. 12 of 2018.

Whereas efforts to develop managerial competencies for a CSA with structural positions are regulated in the Regulation of the Head of the State Administrative Institution Number 19 of 2015 (Perkalan Number 19 Year 2015) concerning Guidelines for Organizing Education and Training of Level III Leadership and the Regulation of the Head of the State Administration Institute Number 20 of 2015 (Perkalan Number 20 year 2015) Concerning Guidelines for Organizing Education and Leadership Level IV Training

Perkalan No. 19 the Year 2015 concerning Guidelines for the Implementation of Diklatpim 3 , state that leadership education and training for officials who will and/or have occupied echelon III structural positions in all Ministries, Institutions, and regional governments is aimed at forming a figure of bureaucratic leader who has a high ability in defining the agency's vision and mission into agency programs and leading its implementation. Furthermore, Diklatpim 4 aims to form a figure of bureaucratic leader who has a high ability to prepare the planning of agency activities as well as leading its implementation as outlined in Perkalan No. 20 the Year 2015.

Based on the Decree of the Head of the State Administration Institution Number 781/K.1/ PDP.09/2019, concerning the Establishment of the Central Sulawesi Regional HRDA as an Accredited Government Education and Training Institute, has the right to organize these programs: 1. Basic Training for Prospective Civil Servants Civil; 2. Diklatpim 4; 3. Diklatpim 3. Central Sulawesi HRDA as the organizer of education and training has substantial responsibility for the quality of the outputs of education and training participants

During this time, education and training services in HRDACentral Sulawesi Province are divided into 3 (three) parts, namely: 1) services before education and training, this includes preparing training facilities and infrastructure as well as human resources consisting of organizers and facilitators, 2) services during the education and training process, whose involved directly are widyaiswara as facilitators or teaching staff assisted by the organizing committee, 3) service after education and training, or posttraining evaluation.

On education and training services perspective, service quality is crucial for the output of training participants, which is consistent with Budiyanti et al (2020: 42), Bolton \& Saxena-Iyer (2009: 92-93), Grove et al (2003: 108-109), who demonstrated that improving the quality of services to consumers is critical because it relates to the image of an institution/organization that provides these services. Education and training contribute to human resource development. Also, it can improve the social, cultural and economic development of a nation. According to Chua (2004: 182), the education and training sector always receives several participants who are still in critical thinking so that the situation sand conditions become very complicated and competitive. Thus, the delivery of efficient services in the education and education sector has an enormous significance and urgency.

In the process of education and training of the CSA, the facilitator has a crucial role which is to carry out education, teaching, and training (Dikjartih) of CSA. Evaluation and Development Diklat in Government Training Institutions, as stated in the Rule of Minister of Administrative Reform and Bureaucratic Reform of the Republic of Indonesia Number 22 of 2014. In other words, the facilitator, as one of the front lines of the quality of education and training services of CSAs, must be able to provide excellent quality services in their effort to establish training participants' satisfaction.

However, based on the initial interviews with 10 participants at Diklatpim level IV, level III, and basic leadership training for prospectives CSA, several statements are describing the training participants' dissatisfaction toward facilitators during the training process.

Furthermore, it showed that the participants of Diklatpim and Diklatsar program have unfavorable perceptions of services provided by facilitators of HRDA of Central Sulawesi during the training process. Also, there are statements related to the ability of facilitators to manage their emotions that are considered inadequate by the training participants. Therefore, the facilitator's emotional intelligence needs to be improved. This is in order to shape participants' perceptions of the good quality of HRDA services in Central Sulawesi Province.

According to Goleman (2005: 45-46), emotional intelligence consists of five dimensions, namely:

1) Self-awareness is the ability to recognize feelings when they occur.

2) self-regulation (managing emotions), is the ability to handle so that feeling can be adequately expressed or in harmony until a balance is achieved in the individual. 
3) Self-motivation (motivating yourself), is the ability to organize emotions as a means to an end.

4) Social awareness (social awareness) is the understanding and sensitivity to the feelings, thoughts, and situations of other people or empathy.

5) Social skills (building relationships) is the ability to recognize each individual's emotions and control them. Before you can control the emotions of others, a person must be able to control his emotions and be able to empathize. Individuals who are great at building relationships with others will be successful in any field that relies on a proper association with others.

Public services are all forms of service activities which carried out by Government Agencies both at the central and regional levels, as well as in the SOEs in the form of goods and / or services, and the aiming is to fulfill the needs of the community (Dwiyanto, 2010: 14).

While the definition that currently serves as the primary reference in the implementation of public service delivery as outlined in Law Number 25 of 2009 Concerning Public Service. It is stated that public service is an activity or series of events to meet the needs of services, by the laws and regulations, for every citizen regarding goods, services, and administrative services provided by public service providers.

Moreover, Nurmandi (2010: 15) argued that public service is an activity which carried out by a person or group of people based on material factors through specific systems, procedures, and methods in order to fulfill the interests of others in proportion of their rights.

Service quality is a general service or attitude toward a particular service, customer impression, or service excellence of the organization. In carrying out services, quality is a crucial component that must be considered in providing services, especially public services. Service quality is very important and as a direct manisfestation of provider's image.

Oliver (1981) (see: Oh (1999: 68-69)) states that service quality is related to meeting the expectations/needs of customers. Service is said to have high quality if it can provide products and services according to the needs and expectations of customers (Pudjarti et al., 2019: 238). In this case, quality is related to excellent service, namely the attitude or way of employees in providing service for customers or the community, satisfactorily (Farida et al., 2020: 141).

Service quality has been conceptualized as the difference between customer expectations regarding the service to be received and the perception of services received (Parasuraman et al., (1994: 193194). Service quality is a multidimensional concept (Parasuraman et al., 1994: 194). Its dimensions can be identified as SERVQUAL which argued by Parasuraman et al (1985: 44-45):

1) Physical Proof (Tangibles)

In the form of physical facilities, equipment, and various communication materials. The company's physical appearance, facilities, and infrastructure and the condition of the surrounding environment are clear evidence of the services provided by the service provider.

2) Reliability

The ability to provide services as promised, trusted, accurate, consistent, and under expectations. Following customer expectations means timely performance, service without errors, sympathetic attitude, and high accuracy.

3) Responsiveness

The willingness of employees and employers to help customers and provide services quickly, also to hear and resolve complaints raised by customers. For example, the readiness of employees in serving customers, speed in the transaction process, and handling customer complaints.

4) Assurance

The ability of employees to generate confidence and trust on promises for consumers. For example, the ability of employees on the appropriate knowledge of the product, the quality of hospitality, attention, and courtesy in providing services, skills in providing information, the ability to provide security in utilizing the services offered, and the ability to instill customer trust in the company. This guarantee dimension is a combination of dimensions:

a) Competence, which includes the skills and knowledge possessed by employees.

b) Courtesy, which consists of the friendliness, attention, and attitude of the employees.

c) Credibility, which covers matters related to trust in the company, such as reputation, achievement, and so on.

5) Empathy

The willingness of employees and employers to give in-depth and exceptional attention to customers by trying to understand customer desires where a company is expected to have an understanding and knowledge of customers and customer needs specifically. This empathy dimension is a combination of dimensions:

a) Access, including the ease of utilizing the services offered by the company 
b) Communication is the ability to communicate to convey information to customers or obtain input from customers

c) Understanding of customers, including the company's efforts to identify and understand customer needs and desires.

Based on the literature review, there are limited studies in the field of education and training of the CSA, especially regarding the relationship between emotional intelligence and service quality. For example, research conducted by Ahuja (2011:121135). In his research on the insurance sector in India, he tries to uncover the relationship between emotional intelligence and performance. This research involved 100 executives who served at the forefront of the service area. In line with him, Lee and Ok (2015: 437-468) conducted the study which investigated the effects of emotional determinants toward service orientation of hotel managers and line employees.

Furthermore, Lee (2018: 729-745) conducted the study which investigates the relationships between the dimensions of emotional intelligence and job satisfaction among public service workers. His study shows that burnout is significantly and negatively affected by emotion regulation and job satisfaction is significantly and positively affected by emotional self-awareness. In line with Lee (2018), Levitats and Vigoda-Gadot (2020: 426-446) in their study about engagement of civil servants, showed the role of managers' and employees' emotional intelligence, in forming employees' public service motivation (PSM) to provide better services to citizens.

In educational sector, Maxwell and Riley (2017: 484-502) conducted the study to uncover the relationships between emotional demands, three emotional labour facets, burnout, wellbeing and job satisfaction. His study included 1320 full-time school principals. In line with Maxwell and Riley (2017), Chen and Guo (2020: 82-105) conducted the study in educational sectoralso. His study is conducted in order to predict the effect of school principals' emotional intelligence, and their instructional leadership, toward impovement teachers' instructional strategies.

As well as in Indonesia, there were several studies which used emotional intelligence as their research domain. Trisnaningsih (2013: 185-195) conducted a study with the purpose to predict the effect of employees' emotional intelligence toward service quality of education and training participants in the Central Sulawesi Provincial Education and Training Personnel Agency. The results showed that emotional intelligence which consists of selfawareness, self-regulation, motivation, empathy and social skills had a significant and strong effect toward service quality of education and training participants in the Central Sulawesi Provincial Education and Training Personnel Agency.

Hanafi(2015: C31-C37) conducted the research regarding the effect of emotional intelligence on emotional exhaustion and its impact on the quality of nursing services at Charitas Hospital in Palembang. The result showed that emotional intelligence had a negative and significant effect on emotional exhaustion. On the other hand, the quality of service in the hospital is significantly influenced by nurses emotional intelligence. Thus, based on previous studies, it appears that the emotional intelligence of facilitators in government training agencies has been overlooked. When the training and learning process takes place, widyaiswara as facilitators will directly provide services to the training participants, which in turned form participants' perception of the quality of the services offered.

Furthermore, Setyaningrum et al (2016: 211220) conducted the study to explain and predict the effect of emotional intelligence toward employees performance. The results showed that self-awareness, self-regulation, motivation, empathy and social skills have a significant effect toward employee performance.

Rauf et al (2019: 225-245) conducted the study which aimed to determine the effect of emotional intelligence on employee performance at the Human Resources Department of PT Semen Tonasa, Pangkep Regency, South Sulawesi. Results showed that emotional intelligence had a significant impact toward employee performance.

Therefore, this study focuses on facilitators' emotional intelligence as in line with George et al (1998: 760) and Lawler (2001: 340), who showed that emotions play an essential role in mediating the dynamics of interpersonal interactions. As in the learning process, facilitators are always involved in interpersonal interaction with the training participants. Some researchers such as Chamanifard et al (2014: 654), Kaura (2011: 166), Kim (2010: 2344), Naeem et al (2011: 56) agree on the importance of the relationship between the emotional intelligence of service providers and service quality. According to their results study, the emotional intelligence of service organization employees has a positive effect toward service quality.

Furthermore, Budiyanti and Patiro, (2018: 335) and Mayer et al (2004: 198) argued that employees who able to understand customer emotion will recognize their own emotions and others, use these emotions to facilitate decision making, and manage 
their emotions to fulfill customer expectations. Thus, impacting customer satisfaction, which demonstrates a positive perception of the service quality he/she receives.

In the field of education and training, it is never separated from the quality of service and satisfaction of training participants when the learning process is ongoing (Budiyanti et al., 2020: 42). When discussing service quality and satisfaction of training participants, this is closely related to the ability of education service providers (Budiyanti et al., 2020: 42).

Parasuraman et al (1985) (as cited by Kassim \& Abdullah (2010: 352); Saleem et al (2017: 1137); Kloutsiniotis \& Mihail (2018: 803)) proposed a model which is known as one of famous model in the service sector, namely Service Quality (SERVQUAL). However, as argued by Hsiao and Lin (2008: 30), this model has several limitations. It's only suitable for service providers in the business sector so that it is not suitable for service providers in the public sector and education sector (RamseookMunhurrun et al., 2010: 38).

Furthermore, the concept of service quality has been focused on using the organization as the unit of analysis (Ko \& Chou, 2020: 12). There are still few studies applying the concept of service quality to measure the performance of services provided by personnel individually (Ko \& Chou, 2020: 12-13). Likewise, with existing studies in Indonesia, the authors have not found the application of the concept of service quality in measuring the performance of individual services, especially in the field of education and training delivered by instructors, facilitators, or widyaiswara.
In the service sector, banking as an example, the delivery of services by banking staff is aimed at service quality, so that service quality is said to be a measure of the suitability of service delivered/ delivery by service officers (Radha \& Prasad, 2013: 62). Therefore, service quality is defined as the result of a process within consumers comparing between expectations with performance in service delivery (Radha \& Prasad, 2013: 63). Thus, the quality of widyaiswara services at BPSDM of Central Sulawesi Province is a process within the training participants to compare the expectations with the service delivery performance of the widyaiswara received during the training process.

Thus, according to Chamanifard et al (2014:654), Kaura (2011: 166), Kim (2010: 2344), and Naeem et al (2011: 56) who stated that there is a need to uncover the relationship between emotional intelligence of service providers with service quality, which will impact the formation of positive perceptions regarding the service quality provided. Thus, the emotional intelligence of employees of a service organization has a positive effect on service quality.

Therefore, in general, this study strives to uncover the effect of facilitators' emotional intelligence toward service quality. The specific objectives of this study are 1) To determine the relationship of facilitators' emotional intelligence to the education and training service quality provided; 2) To identify an indicator of emotional intelligence which most influences service quality.

Thus, the Hypothesis which developed in this study is: facilitators emotional intelligence of HRDA Central Sulawesi Province has a positive effect toward education and training service quality.

Therefore, this research model is as follows:

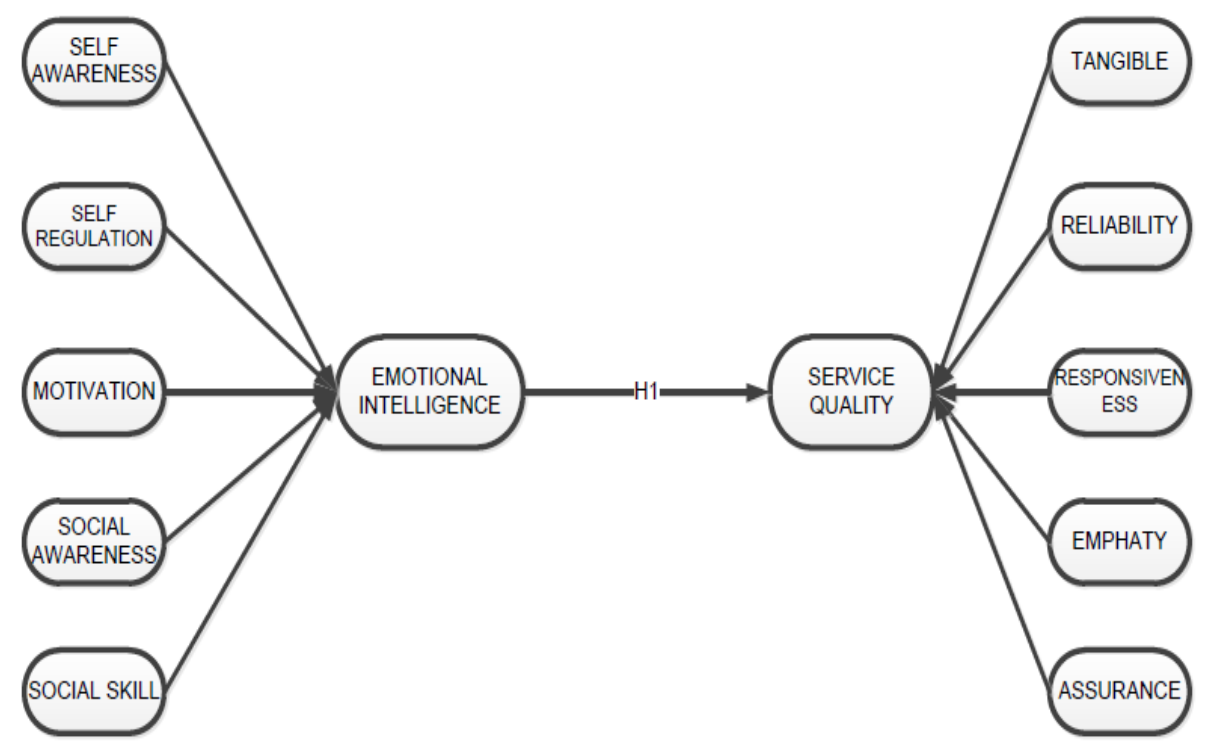

Figure 1. Research Model

Source: Primary Data Processed (2020)

Emotional Intelligence And Service Quality Of Facilitators' Indonesia Human Resources Development Agency (HRDA) (Shine Pintor Siolemba Patiro and Hety Budiyanti) 


\section{METHOD}

Generally, this research is quantitative which conducted in March 2018 until September 2018. This research consisted of two stages. Phase one was held in March 2018 until May 2018. This phase is a preliminary study which aimed to determine the accuracy of the SERVQUAL dimension as argued by Parasuraman et al (1985: 42-43) when applied in the field of training and education. It also included the emotional intelligence of facilitators perceived by the training participants. In this case, training participants were asked about the emotional intelligence of the facilitators and the quality of service attributes that needed to be present in a facilitator of the HRDA in Central Sulawesi. The interview was conducted including 30 Diklatpim participants in HRDA of West Java, Jakarta, Central Sulawesi, and North Sumatera. The aim of this interview to uncover their perception regarding emotional intelligence and perceived service quality.

Furthermore, results of the phase one are used as the basis for building a questionnaire which combined with indicators of each construct developed by previous researchers. As the results of the questionnaire development in phase one, we gained 37 indicators for the two constructs to be tested in this study.

The questionnaires which have been developed was sent back to 500 Diklatpim participants in the HRDA of Central Java, East Java, West Java, Jakarta, Banten, Central Sulawesi, and North Sumatera Provinces through a non-probability sampling with a purposive sampling technique. The determination of the sample size in this study is closely related to the use of Partial Least Square (PLS) Structural Equation Modeling (SEM) as an analytical tool.

According to Chin et al. (1995) that the minimum sample size when using SEM PLS is 5-10 multiplied by the number of indicators (as cited by Gefen et al (2011: A3)). The indicators in this study amounted to 37 indicators, then the minimum sample size used is $5 \times 37=185$. Thus, the minimum sample size determined in this study is 250 people.

However, only $462(92.40 \%$ response rate) questionnaires were returned and eligible for further analysis. Thus the response rate in this study is higher than $80 \%$. According to Neuman (2014: 386) it is feasible for further analysis. Questionnaires which were collected were then processed with the help of the SPSS program to perform Factor Analysis (FA). Based on FA results, 37 indicators have a loading factor value that is above 0.6. Thus, 37 indicators will be used in measuring the three constructs in this study, which are emotional intelligence, service quality, and training participants' satisfaction.

Furthermore, data analysis was conducted using SEM PLS. The main reason for the use of SEM PLS is the existence of constructs with formative indicators, namely emotional intelligence and service quality. The construct of facilitators' service quality was measured using indicators developed by Parasuraman et al., $(1985,1988)$ (as cited by: Lien et al (2014: 404); Silvestri et al (2017: 59). The construct of facilitators' emotional intelligence uses indicators developed by Goleman (2005: 264). Likert scales, 1 to 5, are used for the construct measurement ( 1 = strongly disagree; 2 = disagree; $3=$ neutral; $4=$ agree; $5=$ totally agree).

\section{Data Analysis Techique}

Data analysis techniques use Structural Equation Modeling (SEM) with the help of SMART PLS 2 M3 software and SPSS (Statistical Package for Social Science) 23. SEM two step approach is used as data analysis in this study as proposed by Anderson and Gerbing (1988) (see: Gefen et al (2011)). The Goodness of Fit (GOF) criteria is used as a model evaluation according to Amato et al. (2004), as cited by Tenenhaus et al (2005: 161).

\section{RESULTS AND DISCUSSIONS}

\section{Findings}

Table 1. Respondent Profile

\begin{tabular}{|c|c|c|}
\hline Variable & Total & Percentage $(\%)$ \\
\hline \multicolumn{3}{|l|}{ Sex } \\
\hline Male & 182 & 39.39 \\
\hline Female & 280 & 60.61 \\
\hline \multicolumn{3}{|l|}{ Education } \\
\hline Master & 316 & 68.40 \\
\hline Doctorate & 146 & 31.60 \\
\hline \multicolumn{3}{|l|}{ Tenure } \\
\hline$>15$ years & 462 & 100 \\
\hline \multicolumn{3}{|l|}{ Age } \\
\hline 25-35 year & 18 & 3.90 \\
\hline 36- 45 year & 78 & 16.88 \\
\hline $46-55$ year & 300 & 64.94 \\
\hline$>56$ year & 66 & 14.29 \\
\hline
\end{tabular}

Source: Primary Data Processed (2020)

Based on Table 1, the respondents in this study were dominated by 280 female $(60.61 \%)$, the majority of respondents had an master level, which was 316 people (68.40\%). The majority of respondents in this study had a working period of more than 15 years, which accounted for 462 people $(100 \%)$ with a predominant age between $46-55$ years of 300 people (64.94\%). 
Result of Validity and Reliability test before Structural Equation Modeling (SEM) Testing

Table 2 shows that measurement indicators for each construct produce a factor loading value $>0.3$, implying that the measurement constructs have adequate discriminant validity. Moreover, table 3 demonstrates the Average Variance Extracted (AVE) value obtained through calculations with

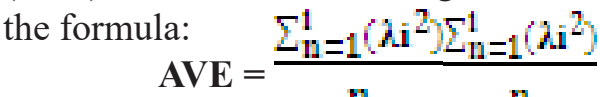

Notes: $\mathrm{n}=$ sum of measurement indicators; $\lambda_{\mathrm{i}}=$ factor loading (Hair et al., 2014).

The results of AVE value which generated in Table 2 are more than 0.5. Thus, the constructs which employed in this study have an appropriate convergence validity (Hair et al., 2014: 619). In this study, the two constructs used are constructs with formative indicators, namely emotional intelligence and service quality. Therefore, AVE value for the two constructs is meaningless.

Table 2. Validity and Reliability Test

\begin{tabular}{cllc}
\hline $\begin{array}{c}\text { Constructs } \\
\text { (alpha) }\end{array}$ & Item & $\begin{array}{c}\text { Factor } \\
\text { Loading }\end{array}$ & $\begin{array}{c}\text { Average } \\
\text { Variance } \\
\text { Extracted }\end{array}$ \\
\hline & SA & $\mathbf{. 6 0 2}$ & \\
Emotional & SR & $\mathbf{. 8 0 8}$ & \\
Intelligence & M & $\mathbf{. 8 5 6}$ & 0,591 \\
$(0,845)$ & SAw & $\mathbf{. 8 2 9}$ & \\
& SS & $\mathbf{. 7 2 0}$ & \\
& Tg & $\mathbf{. 7 1 3}$ & \\
Service Quality & Re & $\mathbf{. 7 5 4}$ & \\
$(0,858)$ & Rsp & $\mathbf{. 7 7 3}$ & 0,614 \\
& Ass & $\mathbf{. 8 4 0}$ & \\
& Emp & $\mathbf{. 8 3 0}$ & \\
\hline
\end{tabular}

Source: Primary Data Processed (2020)

\section{Result of Reliability Test}

The measurement of construct reliability in this study uses Cronbach Alpha $(\alpha)$. According to Nunnaly (1978) and Kaplan \& Saccuzzo (1982) (see: Peterson (1994)) that an adequate $\alpha$ value for each construct which used in basic research is 0.70 to 0.80 . Thus, the construct reliability in this study is satisfactory (see: Table 2). However, for constructs with formative indicators (emotional intelligence and service quality), the value of Cronbach Alpha $(\alpha)$ does not mean anything.

Testing the measurement model (Discriminant Validity and Convergence of Research Constructions) in SEM

Model evaluation in this study was conducted by evaluating the measurement model and the structural model (Chin et al., 2008). In this study, the discriminant validity test was not only assessed based on the loading factor of measurement with its construct (see Table 3), but also by comparing the AVE roots of each construct with the correlation between constructs in the model. If the roots of AVE for each construct are higher than the correlation, the model has sufficient discriminant validity (Chin et al., 2008: 289; Hartono \& Abdilllah, 2009: 32).

Table 3 demonstrates that the discriminant validity for each construct is favorable where loading factor values for the measurement of each construct has met the minimum level following the rule of thumb (Hair et al., 2014). Furthermore, a satisfying discriminant validity was achieved where the square root value of AVE for each construct higher than the correlation between constructs in the model (Chin et al., 2008: 289).

Also, in order to test the formative constructs validity, the bootstrapping process is performed on the Smart PLS program, to produce the indicators outer weight. Based on the latter result, T-statistic value of each indicators should be above 1.96. If there are indicators in each of these formative constructs that have a t-statistic value $<1.96$, then the indicator is not significant in the construct that it forms. Thus the construct is considered not to meet the construct validity test criteria (Hartono \& Abdilllah, 2009: $30)$. Nonetheless, we should not rush to discard the indicators. However, if erasing one of the indicators in the formative construct will have an impact on the definition of the construct (Hartono \& Abdilllah, 2009: 30-31).

Therefore, it is necessary to reexamine the outer loading value. If the value is above 0.5 , then the indicator should not be discarded because it will change the meaning of the construct (Hartono \& Abdilllah, 2009: 30-31). Thus, formative constructs in this study are still considered to meet the construct validity test criteria despite one or more insignificant indicators based on their outer weight values. If the outer loading value is still above 0.5), statistically, the formative construct could be tested further in the structural model (Hartono \& Abdilllah, 2009: 30-31).

Based on Table 4, the t-statistic value for formative construct indicators should be $>1.96$ (t-table). Yet, in this study there are formative construct indicator which values of t-statistic below 1.96, namely: emotional intelligence ( $\mathrm{M}=$ $0.447739 ; \mathrm{SR}=0.850697$ ) and service quality (Ass $=1.515059 ; \mathrm{Emp}=1.276311 ; \mathrm{Re}=1.182650)$. Thus, the outer loading value for these indicators need to be reexamined, and the results show that the value is above 0.5 (see Table 4 ). 
Table 3. Measurement Model Evaluation Result for Constructs with Formative Indicator (outer weight and outer loading)

\begin{tabular}{|c|c|c|c|c|}
\hline & $\begin{array}{c}\mathbf{T} \\
\text { Statistics } \\
(\mid \mathbf{O} / \\
\text { STERR|) } \\
\end{array}$ & & $\begin{array}{c}\text { Emotional } \\
\text { Intelligence } \\
\text { (outer } \\
\text { loading) } \\
\end{array}$ & $\begin{array}{c}\text { Service } \\
\text { Quality } \\
\text { (outer } \\
\text { loading) }\end{array}$ \\
\hline $\begin{array}{l}\text { Ass -> Service } \\
\text { Quality }\end{array}$ & 1.515059 & Ass & & 0.714243 \\
\hline $\begin{array}{l}\text { Emp -> Service } \\
\text { Quality }\end{array}$ & 1.276311 & Emp & & 0.627340 \\
\hline $\begin{array}{l}\text { M -> Emotional } \\
\text { Intelligence }\end{array}$ & 0.447739 & M & 0.571358 & \\
\hline $\begin{array}{l}\text { Re -> Service } \\
\text { Quality }\end{array}$ & 1.182650 & $\operatorname{Re}$ & & 0.620591 \\
\hline $\begin{array}{l}\text { Rsp -> Service } \\
\text { Quality }\end{array}$ & 4.250889 & Rsp & & 0.830150 \\
\hline $\begin{array}{l}\text { SA -> } \\
\text { Emotional } \\
\text { Intelligence }\end{array}$ & 2.416129 & SA & 0.648023 & \\
\hline $\begin{array}{l}\text { SAw -> } \\
\text { Emotional } \\
\text { Intelligence }\end{array}$ & 3.725229 & SAw & 0.793154 & \\
\hline $\begin{array}{l}\text { SR -> } \\
\text { Emotional } \\
\text { Intelligence }\end{array}$ & 0.850697 & SR & 0.585953 & \\
\hline $\begin{array}{l}\text { SS -> } \\
\text { Emotional } \\
\text { Intelligence }\end{array}$ & 3.129588 & SS & 0.828999 & \\
\hline $\begin{array}{l}\mathrm{Tg}->\text { Service } \\
\text { Quality }\end{array}$ & 2.022545 & $\mathrm{Tg}$ & & 0.617869 \\
\hline
\end{tabular}

Source: Primary Data Processed (2020)

Thus, the formative construct in this study, namely: emotional intelligence and service quality may be further tested in the structural model. Structural model testing is carried out to predict causality relationships between latent variables to reveal the validity of the theoretical model of the study by testing the research hypothesis (Hair et al., 2014: 640). Furthermore, it was carried out by evaluating the value of the path coefficient and t-statistic or Critical Ratio (CR) value to test the significance of the constructs in the structural model (Hair et al., 2014: 649). Figure 2 shows the structural model after the analysis of the measurement model, which includes the relationship of the effect between each research construct.

In this study, to evaluate the structural model, it begins with examining the R-square value for each endogenous variable (service quality) which generated by Smart PLS. The R-Square value (0.609) indicates the ability of the exogenous variables in explaining the variance of the endogenous variables. The results suggest that the ability of emotional intelligence in explaining variance of service quality is $60.9 \%$. Chin (1998) and Hock \& Ringle (2006) (as cited by Garson (2016: 214)) determine the R-square value categories strongly, moderately, and weakly. R-square value of 0.67 is categorized as strong, 0.33 is classified as moderate, and 0.19 is categorized as weak (Chin (1998) and Hock \& Ringle (2006) (as cited by Garson (2016: 214)).Thus, this research model shows that emotional intelligence can explain the service quality.

Furthermore, f square (effect size) value (0.417) shows the effect of the independent latent variable on the dependent latent variable. Effect size values can be grouped into three categories: weak (0.02), moderate (0.15), and strong (0.35) (Kock, 2103; Hair et al., 2013) (as cited by Sholihin \& Ratmono (2014: 64)) The effect size value which is below 0.02 indicates that the influence of the independent variable is very weak when viewed from a practical point even though it has a significant $p$ value. The results of this study indicate that emotional intelligence has a relatively large effect on service quality (0.417).

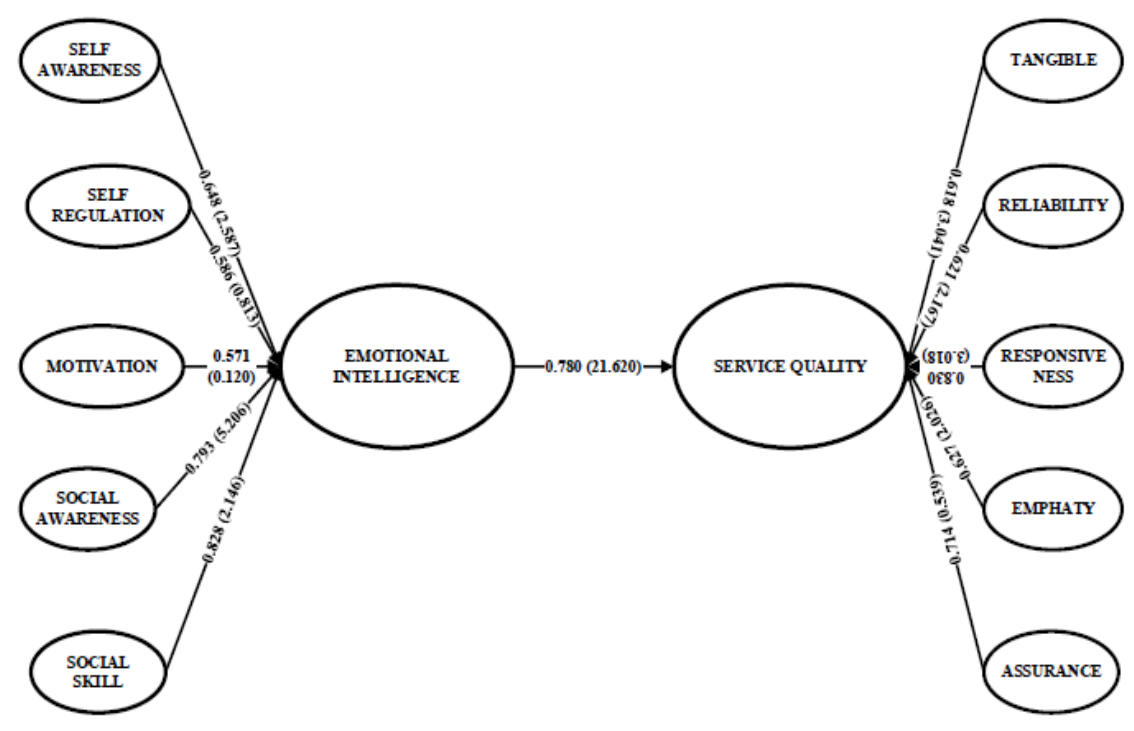

Figure 2. Measurement and Structural Modeling

Source: Primary Data Processed (2020)

Emotional Intelligence And Service Quality Of Facilitators' Indonesia Human Resources Development Agency (HRDA) (Shine Pintor Siolemba Patiro and Hety Budiyanti) 
Q-square (the Stone-Geisser coefficient) is a non-parametric measure which obtained through the blindfolding algorithm (Sholihin \& Ratmono, 2014: 72-73). This coefficient is used to assess the relevance or predictive validity from a set of predictor latent variables on the criterion latent variable (Sholihin \& Ratmono, 2014: 72-73). Models which have Q-square values greater than zero indicate good predictive validity (Sholihin \& Ratmono, 2014: 7273). Thus, results of this research show a favorable predictive validity model where the Q-square value is above zero $(0.255)$.

Overall the Goodness of Fit (GoF) index of the model is calculated based on the formula proposed by Tenenhaus et al (2005):

$$
\begin{gathered}
\mathrm{GoF}= \\
\sqrt{\text { communality mean } X R-\text { square mean }} \\
\sqrt{\text { communality mean } X R-\text { square mean }}
\end{gathered}
$$

\section{Note: mean (average)}

In this study, the average value of communality is 0.457 , and the average value of the R-square is 0.609 . Thus the Goodness of Fit (GoF) index of the research model is $=0.528$. As stated by Tenenhaus et al (2005) that a GoF value which more than or equal

\begin{tabular}{|c|c|c|c|c|}
\hline $\begin{array}{c}\text { Research } \\
\text { Hypothesis }\end{array}$ & $\begin{array}{c}\text { Parameter } \\
\text { Estimation, } \\
\text { Regression } \\
\text { Coefficient } \\
\text { Standardization }\end{array}$ & $\begin{array}{l}\text { Critical } \\
\text { Ratio } \\
\text { (CR) } \\
=\mathbf{t}\end{array}$ & Direction & Decision \\
\hline $\begin{array}{l}\text { H1: } \\
\text { Emotional } \\
\text { intelligence } \\
\text { has a } \\
\text { positive } \\
\text { effect on } \\
\text { service } \\
\text { quality of } \\
\text { HRDA of } \\
\text { Central } \\
\text { Sulawesi } \\
\text { Province }\end{array}$ & 0.780 & 21.620 & $\begin{array}{l}\text { Positive, } \\
\text { as } \\
\text { expected }\end{array}$ & Supported \\
\hline
\end{tabular}
to 0.5 can be categorized as favorable.

Table 4. SEM Estimation Result and Hypothesis Testing

Source: Primary Data Processed (2020)

Table 4 shows that all research hypotheses are supported which Critical Ratio (CR) or t-statistic value is significant and has a direction following the hypothesis, which is positive. The recommended $\mathrm{CR}$ value in SEM analysis to show an adequate significance level is more than 1.96 (Garson, 2016: 152).

Emotions displayed by service providers in the service delivery process are considered as service elements which directly affect customer perceptions about service quality (Kandampully, 1998: 432). Therefore, in the education and training sector, emotional intelligence of facilitators is as an important as an essential factor in handling the emotional demands of training participants. Fatt \& Howe (2003: 348) in their study state that the ability of service providers to recognize, manage, and understand customer emotions will affect the attitudes and behaviors involved in the sales process. In other words, the ability of a facilitator's emotional intelligence when interacting determines how training participants are served and thus affects the perceived quality of service. Furthermore, in this case, facilitators, as one of the front liners in the provision of education and training services, are required to have the high emotional intelligence to manage interactions with training participants more effectively. They are considered competent in resolving conflicts with the training participants, because they are able to manage their emotions and the participants.

Research conducted by Kim (2010: 2345) shows that emotional intelligence is strongly associated with emotional expression and has an indirect effect on perceived service quality. Following Kim (2010), Naeem et al (2011: 58), in his study on private/foreign banking in Pakistan, also showed that emotional intelligence is a positive predictor of a higher quality of service. In line with them, research conducted by Pugh (2001: 10181027) regarding banking employees shows the similar results. Emotional expressions and positive affection which are shown by employees affect customer perceptions about service quality. Finally, in a study of service quality in the hospitality industry, in India, Chamanifard et al (2014: 654) found that emotional intelligence has a positive effect toward service quality significantly. According to them, four dimensions of the SERVQUAL model (except assurance) have a significant effect toward employee emotions positively.

One of this Research Objectives aimed to investigate whether or not facilitator's emotional intelligence is correlated to their service quality in HRDA. The hypotheses are supported based on the empirical results. As shown by the SEM analysis, the emotional intelligence was strongly correlated with the service quality.

As a matter of fact that service facilitators with high emotional intelligence are more likely to satisfy customers' expectations, which in turn affecting their perceptions of service quality. As an example, facilitators whose high emotional intelligence can 
interpret the emotional cues in verbal and non-verbal communication (e.g. facial expression, voice) of frustrated trainee accurately when they undergo education and training at HRDA.

Furthermore, facilititators are enable to engage positive emotions at work if they can understand and facilitate emotional nicely. Apart from creativity and innovative ideas, a happy and positive mood also encourages the formation of harmonious working relationships with others (Budiyanti \& Patiro, 2018: 231). Moreover, Budiyanti \& Patiro (2018: 232) argued, with high emotional facilitation, people can utilise the changing moods of the customer in carrying out their jobs sensibly and smoothly.

Facilitators of HRDA who are able to deal with stress effectively and work well under pressure are due to their high emotional intelligence and ability to regulate and manage their emotions (Budiyanti \& Patiro, 2018: 238). Therefore, the perceived service quality of trainee could be shaped because of facilitators competence in solving problems and making appropriate decisions.

Results of this study are consistent with Kiely (2005), who shows at each stage of most service processes, emotional interactions occur and affect the memory depending on consumer perceptions in regard the service performance. As stated by Pugh (2001: 1019) that the emotional expression of service personnel will influence the customer's assessment of the quality of the service. In line with Pugh (2001), Mayer et al (2004: 198) in their study argued that people will be more confident and friendly because of high emotional intelligence, and excellent interpersonal relationships will be built by such attitudes. Thus, the results of this study indicate that the emotional intelligence possessed by facilitators of HRDA Central Sulawesi Province influences shaping the participants' perceptions of the quality of service provided during the training process.

The results of this study also indicate that the dimension of emotional intelligence with the most significant effect on service quality is Social Awareness. This conclusion is drawn from the outer weight value of T statistics in Table 7, which is 3.725. As stated by Mayer \& Salovey (2003: 198 ) that social-awareness is one part of social competence. Furthermore, Mayer \& Salovey (2003: 198) stated that social awareness is an individual effort to understand and comprehend how to build an emotional relationship with the people around him regardless of their class or background.

Goleman (1998: 25-26; 2005: 46) states that there are several indicators of social awareness, namely: (1) empathy, one's ability to recognize and understand the feelings of others, understand their perspectives, and actively participate in each topic discussed, 2)awareness to participate in organizations, understand something that is happening, determine network patterns, and how to organize and adjust to the level of a team group, and 3) recognize each other and understand each other's needs to achieve goals.

\section{CONCLUSIONS}

Results showed that social awareness of facilitators when implementing the learning process in education and training activities organized by HRDA of Central Sulawesi province can shape the positive perception of the training participants on the quality of services received. In other words, a facilitator's ability to make a personal approach to the training participants made them well accepted. This research is probably the first study to uncover the effect of emotional intelligence (EI) toward service quality (SQ) for facilitators in Indonesia HRDA as evidenced from the lack of literature unearthed during the literature review period. This because of based on the literature review, researcher did not find any empirical study examining the correlations of EI and SQ especially in Indonesia HRDA context. This study only consists of training participants in the civil service as respondents. For the next research, we expected it could include other training participants as respondents in different programs, such as technical training. Second, this study only include facilitators at one HRDA province in Indonesia. Therefore, expanding the area of study is necessary, which includes facilitators of other HRDA from other regions. The aiming is to generalize research results, especially which is related to emotional intelligence. Furthermore, it's necessary to conduct comparative study with Indonesia HRDA in other provinces in order to identify the different effects of service quality dimensions and their impact on satisfaction. Also, the role of cultural issues can be used as a consideration for expanding elaboration of current research model.

\section{REFERENCES}

Ahuja, A. (2011) Emotional Intelligence as a Predictor of Performance in Insurance Sector. Asia-Pacific Business Review, 7(2): 121-135.

Bolton, R. \& Saxena-Iyer, S. (2009). Interactive Services: A Framework, Synthesis and Research Directions. Journal of Interactive Marketing, 23(1), 91-104.

Budiyanti, H., Patiro, S.P.S., Djajadi, M. \& Astuty, S. (2020). Does Service Quality in Education 
and Training Process Matters? Study of Government's Human Resources Agencies in Indonesia. Journal on Effieciency and Responsibility in Education and Science, 13(1), 41-55.

Budiyanti, H. \& Patiro, S.P.S. (2018). Perceived fairness, emotions, and intention of fast food chain restaurants customers in Indonesia. Gadjah Mada International Journal of Business, 20(2), 229-245. https://doi. org/10.22146/gamaijb.30136

Chen, J. \& Guo, W. (2020). Emotional intelligence can make a difference: The impact of principals' emotional intelligence on teaching strategy mediated by instructional leadership. Educational Management Administration \& Leadership, 48(1) 82-105

Chamanifard, R., Nikpour, A. \& Chamanifard, S. (2014). Investigating the impact of emotional intelligence on organizational performance in International Division of Tejarat Bank, Iran. International Journal of Scientific Management and Development, 2(11), 652657.

Chin, W.W., Peterson, R.A. \& Brown, S.P. (2008). Structural Equation Modeling in Marketing: Some Practical Reminders. The Journal of Marketing Theory and Practice, 16(4), 287-298. https://doi.org/10.2753/MTP10696679160402

Chua, C. (2004). Perception of Quality in Higher Education. Proceedings of the Australian Universities Quality Forum 2004.

Dwiyanto, A. (2010). Manajemen Pelayanan Publik:Peduli, Inklusif, dan Kolaboratif. Yogyakarta: Gamapress.

Farida, I., Setiawan, R. \& Esra. (2020). The Influence Of Employee Participation On Archive Management At Bandar Lampung Cultural And Educational Department. Sosiohumaniora 22(2), 140-145.

Fatt, J.P.T. \& Howe, I.C.K. (2003). Emotional intelligence of foreign and local university students in Singapore: Implications for managers. Journal of Business and Psychology, 17(3), 345-367.

Garson, G.D. (2016). Partial Least Squares: Regression and Structural equation Models. Statistical Associates Blue Book Series. Asheboro, USA: Statistical Publishing Associates
Gefen, D., Rigdon, E.E. \& Straub, D. (2011). An Update and Extension to SEM Guidelines for Administrative and Social Science Research. MIS Quarterly, 35(2), A1-A7. https://doi. org/10.1016/j.lrp.2013.01.001

George, J.M., Jones, G.R. \& Gonzales, J.A. (1998). The Role of Affect in Cross-Cultural Negotiations. Journal of International Business Studies, 29(4), 749-772.

Goleman, D. (1998). Working with emotional intelligence. New York: Bantam Books

Goleman, D. (2005). Emotional intelligence: Why it can matter more than IQ for character. New York: Bantam Books.

Grove, S.J., Fisk, R.P. \& John, J. (2003). The Future of Services Marketing: Forecasts from Ten Services Experts. Journal of Services Marketing, 17(2), 107-121.

Hair, J.F. Jr, Sarstedt, M., Hopkins, L. \& Kuppelwieser, V. G.. (2014). Partial least squares structural equation modeling (PLS-SEM): An emerging tool in business research. European Business Review, 26(2), 106-121.

Hanafi, A. (2015). Pengaruh Kecerdasan Emosional (Emotional Intelligence)Terhadap Kelelahan Emosional (Burnout) dan Dampaknya terhadap Kualitas Pelayanan Perawat RS.RK.Charitas Palembang. Prosiding Seminar Nasional Forum In Research, Science, and Technology (FIRST).

Hartono, J.M \& Abdilllah, W. (2009). Konsep dan Aplikasi PLS (Partial Least Square) Untuk Penelitian Empiris (1st ed.). Yogyakarta: BPFE.

Hsiao, C. \& Lin, J. (2008). A Study of Service Quality in Public Sector. International Journal of Electronic Business Management, 6(1), 29-37.

Kandampully, J. (1998). Service quality to service loyalty: A relationship which goes beyond customer services. Total Quality Management, 9(6), 431-443

Kassim, N. \& Abdullah, N. A. (2010). The effect of perceived service quality dimensions on customer satisfaction, trust, and loyalty in e-commerce settings: A cross cultural analysis. Asia Pacific Journal of Marketing and Logistics, 22(3), 351-371..

Kaura, P. (2011). Enormity of emotional intelligence in Indian banking sector. Asia Pacific Journal of Research in Business Management, 2(1), 165-177. 
Kiely, J.A. (2005). Emotions in business-to-business service relationships. The Service Industries Journal, 25(3), 373-390.

Kim, S.H. (2010). The effect of emotional intelligence on salesperson's behavior and customers' perceived service quality. African Journal of Business Management, 4(11), 2343-2353.

Kloutsiniotis, P.V. \& Mihail, D.M. (2018). The link between perceived high-performance work practices,employee attitudes and service quality: The mediating and moderating role of trust. Employee Relations, 40(5), 801-821

Ko, C. \& Chou, C. (2020). Apply the SERVQUAL Instrument to Measure Service Quality for the Adaptation of ICT Technologies: A Case Study of Nursing Homes in Taiwan. Healthcare, 8 (108), 1-16.

Lawler, E.J. (2001). An affect theory of social exchange. American Journal of Sociology, 107(2), 321-352.

Lien, C., Wu, J., Chen, Y. \& Wang, C. (2014). Trust transfer and the effect of service quality on trust in the healthcare industry. Managing Service Quality, 24(4), 399-416.

Lee, H. J. (2018). How emotional intelligence relates to job satisfaction and burnout in public service jobs. International Review of Administrative Sciences, 84(4), 729-745.

Lee, J. \& Ok, C. (2015). Examination of Factors Affecting Hotel Employees' Service Orientation: an Emotional Labor Perspective. Journal of Hospitality \& Tourism Research, 39(4), 437-468

Levitats, Z. \& Vigoda-Gadot, E. (2020). Emotionally Engaged Civil Servants: Toward a Multilevel Theory and Multisource Analysis in Public Administration. Review of Public Personnel Administration, 40(3) 426-446

Maxwell, A. \& Riley, P. (2017) Emotional demands, emotional labor and occupational outcomes in school principals: Modelling the relationships. Educational Management Administration \& Leadership, 45(3): 484-502

Mayer, J.D., Salovey, P. \& Caruso, D. R. (2004). "Emotional intelligence: Theory, findings, and implications." Psychological Inquiry, 15(3), 197-215.

Mayer, J.D. \& Salovey, P. (2003). The Intelligence of Emotional Intelligence. Intelligence, 17(4), 433-442.
Naeem, H., Saif, M. I. \& Khalil, W. (2011). Emotional intelligence and its impact on service qualityempirical evidence from the Pakistani banking sector. International Business \& Economics Research Journal, 7(12), 55-62.

Neuman, W.L. (2014). Social Research Methods: Qualitative and Quantitative Approaches (7th ed.). Essex, UK: Pearson Education Limited.

Nurmandi, A. (2010). Manajemen Pelayanan Publik. $1^{\text {st }}$ edition. Yogyakarta: PT. Sinergi Visi Utama.

Oh, H. (1999). Service quality, customer satisfaction, and customer value: A holistic perspective. Hospitality Management, 18(1), 67-82.

Parasuraman, A., Zeithaml, V. A. \& Berry, L. L. (1985). A Conceptual Model of Service Quality and Its Implications for Future Research. The Journal of Marketing, 49(4), 41-50.

Parasuraman, A., Zeithaml, V. A. \& Berry, L. L. (1994). SERVQUAL: alternative scales for measuring service quality? A comparative assessment based on psychometric and diagnostic criteria. Journal of Retailing, 70(1), 193-199.

Peraturan Kepala Lembaga Administrasi Negara Nomor 19 Tahun 2015 Tentang Pedoman Penyelenggaraan Pendidikan dan Pelatihan Kepemimpinan Tingkat III

Peraturan Kepala Lembaga Administrasi Negara Nomor 20 Tahun 2015 Tentang Pedoman Penyelenggaraan Pendidikan dan Pelatihan Kepemimpinan Tingkat IV

Peterson, RA.(1994).AMeta-Analysis of Cronbach's Coefficient Alpha. Journal of Consumer Research, 21(2), 381-391.

Pudjarti, S., Nurchayati \& Putranti, H. R. D. (2019). Hubungan E-Service Quality Dan E-Loyalty Dengan E-Satisfaction Pada Konsumen Go-Jek Dan Grab Di Kota Semarang. Sosiohumaniora - Jurnal Ilmu-Ilmu Sosial Dan Humaniora, 21(3), 237-246.

Pugh, S. D. (2001). Service with a smile : Emotional contagion in the service encounter. Academy of Management Journal, 44(5), 1018-1027

Ramseook-Munhurrun, P., Lukea-Bhiwajee, S. D. \& Naidoo, P. (2010). Service Quality In The Public Service. International Journal of Management and Marketing Research, 3(1), $37-50$. 
Radha, S. \& Prasad, N. (2013). A study on customer orientation as between Emotional Intelligence and Service Performance in Banks. International Journal of Business and Management Invention, 2 (5): 60-66.

Rauf, R., Dorawati, A. \& Hardianti (2019). Pengaruh Kecerdasan Emosional Terhadap Kinerja Karyawan pada PT. Semen Tonasa Kabupaten Pangkep. SEIKO, Journal of Management \& Business, 2(2), 225-245

Saleem, M. A., Zahra, S. \& Yaseen, A. (2017) Impact of service quality and trust on repurchase intentions - the case of Pakistan airline industry. Asia Pacific Journal of Marketing and Logistics, 29(5), 1136-1159.

Setyaningrum, R., Utami, H.N. \& Ruhana, I. (2016). Pengaruh Kecerdasan Emosional Terhadap Kinerja (Studi Pada Karyawan PT. Jasa Raharja Cabang Jawa Timur). Jurnal Administrasi Bisnis (JAB), 36(1), 211-220
Sholihin, M. \& Ratmono, D. (2014). Analisis SEMPLS dengan WarpPLS 3.0. Yogyakarta: Penerbit Andi.

Silvestri,C., Aquilani, B. \& Ruggieri, A. (2017). Service quality and customer satisfaction in thermal tourism. The TQM Journal, 29(1), 55-81.

Tenenhaus, M., Vinzi, V. E., Chatelin, Y. M., \& Lauro, C. (2005). PLS path modeling. Computational Statistics and Data Analysis, 48(1), 159-205. https://doi.org/10.1016/j.csda.2004.03.005

Trisnaningsih, Y. (2013). Pengaruh Kecerdasan Emosional Pegawai Terhadap Kualitas Pelayanan Peserta Pendidikan Dan Pelatihan Pada Badan Kepegawaian Pendidikan Dan Pelatihan Daerah Provinsi Sulawesi Tengah. E-Jurnal Katalogis, 1(7), 185-195. 